\title{
PERAN KOMPLEKS JUKSTAGLOMERULUS TERHADAP RESISTENSI PEMBULUH DARAH
}

\author{
Renny M. Toreh \\ Sonny J. R. Kalangi \\ Sunny Wangko
}

\begin{abstract}
Bagian Anatomi-Histologi Fakultas Kedokteran Universitas Sam Ratulangi Manado
Email: sonnykalangi@yahoo.com
\end{abstract}

\begin{abstract}
Abstrak: As the main structural component of the renin-angiotensin-aldosterone system (RAAS), the juxtaglomerular complex plays a very important role in the regulation of vascular resistance. The synthesis and release of renin into the circulation occurs due to the decrease of blood pressure, loss of body fluid, and a decrease of sodium intake. Renin converts angiotensinogen into angiotensin I, which is further converted by the angiotensin converting enzyme (ACE) into angiotensin II. This angiotensin II causes vasoconstriction of blood vessels, resulting in an increase of vascular resistance and blood pressure. The ACE inhibitors and the angiotensin receptor blockers (ARBs) do not inhibit the RAAS completely since they cause an increase of renin activity. The renin blockers are more effective in inhibiting RAAS activity; therefore, these renin blockers can be applied as antihypertensive agents with fewer side effects. The RAAS activity can be inhibited by a decrease of renin synthesis in the juxtaglomerular complex by blocking the signals in the juxtaglomerular complex that stimulate renin synthesis, and by blocking the gap junctions in the juxtaglomerular complex.
\end{abstract}

Keywords: juxtaglomerular complex, vascular resistance, RAAS.

\begin{abstract}
Abstrak: Kompleks jukstaglomerulus sebagai komponen struktural utama sistem renin angiotensin berperan penting dalam pengaturan resistensi pembuluh darah. Sintesis dan pelepasan renin ke sirkulasi terjadi karena tekanan darah yang rendah, kehilangan cairan tubuh, dan kurangnya intake natrium. Renin akan memecah angiotensinogen menjadi angiotesin I yang kemudian secara cepat dikonversi oleh enzim pengonversi angiotensin menjadi angiotensin II. Angiotensin II menyebabkan vasokontriksi pembuluh darah sehingga meningkatkan resistensi pembuluh darah yang pada akhirnya akan meningkatkan tekanan darah. ACEinhibitor dan ARB kurang sempurna dalam menghambat kerja SRAA oleh karena keduanya memutuskan rantai mekanisme timbal balik sehingga meningkatkan aktifitas renin. Penghambat renin lebih efektif digunakan untuk menghambat aktifitas SRAA sehingga penghambat renin dapat digunakan sebagai obat anti-hipertensi dan memiliki efek samping yang rendah. Metode penghambatan SRAA yang juga dapat dikembangkan ialah penghambatan sintesis renin dalam kompleks jukstaglomerulus dengan cara menekan sinyalsinyal dalam kompleks jukstaglomerulus yang merangsang sintesis renin dan menghambat fungsi taut kedap yang terdapat dalam kompleks jukstaglomerulus.
\end{abstract}

Kata kunci: kompleks juksta glomerulus, resistensi vaskular, SRAA.

Dewasa ini hipertensi telah merupakan masalah global. Berbagai jenis obat antihipertensi telah dikembangkan dan diaplikasikan untuk pengobatan hipertensi, antara lain obat-obat golongan diuretik, ACE inhibitors, angiotensin receptor blockers, dan calcium channel blockers, tetapi angka kejadian hipertensi belum dapat diturunkan. 
Menurut data dari the National Health and Nutrition Examination Survey (NHNES), angka kejadian hipertensi mengalami peningkatan dari tahun ke tahun. ${ }^{1}$

Gejala hipertensi hampir selalu ditemukan pada pasien penyakit ginjal. Keadaan hipertensi yang berkepanjangan dapat menimbulkan kerusakan fungsi ginjal. ${ }^{1}$ Oleh karena itu diperlukan pemahaman lebih mendalam tentang pengaturan tekanan darah di dalam tubuh sehingga dapat ditemukan solusi yang tepat untuk mengontrol tekanan darah.

Salah satu faktor yang memengaruhi tekanan darah ialah resistensi pembuluh darah, yang dipengaruhi oleh tonus pembuluh darah. Terdapat sejumlah bahan yang memengaruhi tonus pembuluh darah, di antaranya yaitu angiotensin II yang merupakan produk dari sistem renin angiotensin. $^{2}$

Sistem renin - angiotensin - aldosteron (SRAA) merupakan suatu regulator yang sangat penting untuk mengatur keseimbangan natrium, volume cairan ekstrasel, resistensi pembuluh darah ginjal, dan resistensi vaskular sistemik. ${ }^{3}$ SRAA diaktifkan oleh enzim renin; oleh karena itu, riset mengenai tekanan darah tinggi dan pengembangan obat-obatannya telah difokuskan pada pengontrolan berbagai titik dalam SRAA. ${ }^{1}$

Struktur yang berperan dalam pengaktifan SRAA ialah kompleks jukstaglomerulus. Kompleks jukstaglomerulus merupakan suatu struktur istimewa dan unik yang terdapat di dalam ginjal dan memiliki fungsi fisiologik yang sangat penting sehingga diperlukan pemahaman mengenai perannya terhadap pengaturan resistensi pembuluh darah. $^{4}$

\section{Komunikasi intersel dalam kompleks jukstaglomerulus}

Pemeliharaan fungsi dan struktur ginjal membutuhkan komunikasi intersel yang terkoordinasi, yang diperantarai oleh faktor-faktor autokrin dan parakrin termasuk neurotransmiter, hormon, faktor-faktor pertumbuhan, dan bahan-bahan vasoaktif.
Komunikasi langsung dari sel ke sel melalui suatu taut kedap telah diketahui sebagai mekanisme yang penting dalam regulasi fungsi ginjal, khususnya fungsi kompleks jukstaglomerulus. Sel-sel makula densa dan sel-sel endotel tubulus bertindak sebagai sensor yang mengamati perubahan konsentrasi ion $\mathrm{Na}$ dan tekanan darah, kemudian mengirimkan sinyal tersebut ke sel-sel efektor yaitu sel-sel otot polos pembuluh darah dan sel-sel jukstaglomerulus untuk mengatur regulasi tonus vaskular pre-glomerulus dan sekresi renin. ${ }^{5}$

Respon fisiologik ini membutuhkan komunikasi intersel yang terkoordinasi dengan baik. Terdapat banyak saluran taut kedap dalam kompleks jukstaglomerulus yang terletak secara proporsional untuk memantau dan mengintegrasikan sinyalsinyal pemicu seperti tekanan, hormon, dan ion-ion, kemudian mengirim informasi tersebut ke sel-sel efektor. Taut kedap menghubungkan sel-sel mesangial, sel-sel otot polos vaskular, sel-sel endotelial, dan sel-sel penghasil renin, sehingga sel-sel tersebut dapat berfungsi sebagai satu kesatuan sistem yang terkoordinasi dengan baik. $^{5}$

\section{Peran taut kedap dalam fungsi kompleks juktaglomerulus}

Taut kedap menyediakan suatu jalur transmisi intrasel untuk molekul-molekul pembawa sinyal. Bertolak belakang dengan jalur ekstrasel dari faktor pertumbuhan, hormon, atau neurotransmiter, jalur intrasel mengirim sinyal dengan menyebrangi membran sel. Molekul pembawa sinyal yang berukuran $<1,2 \mathrm{kDa}$ dapat melewati taut kedap, dan juga second messengers seperti cAMP, ATP, IP3, dan $\mathrm{Ca}^{2+}$ dapat dikirim melalui taut kedap. Sebagai second messenger, $\mathrm{Ca}^{2+}$ sangat berperan dalam pengontrolan banyak fungsi sel termasuk fungsi kompleks jukstaglomerlus. ${ }^{5}$

Secara morfologik, tidak terdapat taut kedap di antara makula densa dan sel-sel mesangial. Mediator yang berperan dalam pengiriman $\mathrm{Ca}^{2+}$ dari makula densa ke selsel mesangial ialah ATP. ATP dilepaskan 
dari sel-sel makula densa (MDCs) sebagai respon terhadap peningkatan konsentrasi $\mathrm{NaCl}$ dalam lumen tubulus. Pengikatan ATP pada reseptor-reseptor $\mathrm{P}_{2} \mathrm{Y}$ dalam selsel makula densa mengakibatkan peningkatan konsentrasi $\mathrm{Ca}^{2+}$ intrasel, yang kemudian dikirim ke sel-sel otot polos vaskular (VSMCs) dan sel-sel penghasil renin (RSCs) melalui taut kedap. Selain itu, peningkatan tekanan darah dalam arteriol aferen akan mengaktifkan sel-sel endotel (ECs) sehingga menyebabkan terjadinya peningkatan konsentrasi $\mathrm{Ca}^{2+}$ intra-sel dan pelepasan ATP ekstrasel. ${ }^{5}$

Taut kedap dan ATP yang tergantung $\mathrm{Ca}^{2+}$ menyebabkan $\mathrm{Ca}^{2+}$ dapat disebarkan dari sel-sel sensor ke sel-sel efektor dalam kompleks jukstaglomerulus, dan dengan demikian mengatur koordinasi kontraktilitas dan respon-respon sekresi dalam kompleks jukstaglomerulus. Sinyal-sinyal $\mathrm{Ca}^{2+}$ yang dihasilkan sel-sel endotel oleh karena adanya rangsangan lain seperti angiotensin II (ANG II) juga dapat dikirimkan ke sel-sel otot polos vaskular dan sel jukstaglomerulus melalui taut kedap. ${ }^{5}$

\section{SISTEM RENIN ANGIOTENSIN}

Sistem renin angiotensin telah dinyatakan sebagai suatu sistem endokrin, parakrin, autokrin dan intrakrin. ${ }^{6}$ Sistem renin angiotensin juga merupakan suatu regulator yang sangat penting untuk mengatur keseimbangan natrium, volume cairan ekstrasel, resistensi ginjal dan resistensi vaskular sistemik. Jadi, sistem renin angiotensin berfungsi sebagai regulator tekanan darah arterial yang paling kuat. ${ }^{7}$ Penghambatan farmakologik dari sistem renin angiotensin secara luas digunakan sebagai pengobatan terhadap pasien hipertensi, gagal jantung kongesti, disfungsi ventrikel, edema paru dan sistemik, diabetes nefropati, sirosis hepatis, scleroderma, dan migrain.,

Sistem renin angiotensin memiliki beberapa komponen penting., ${ }^{9,10}$ Komponenkomponen sistem renin-angiotensin dapat ditemukan di dalam otak, berbagai jaringan perifer seperti pada jantung, ginjal, plasenta, testis, jaringan adiposa, dan pada mata. ${ }^{10,11}$ Komponen-komponen tersebut yaitu: renin, angiotensinogen, angiotensin converting enzyme (ACE), dan angiotensin II. ${ }^{9,10}$

\section{Pengontrolan sekresi renin dari kompleks jukstaglomerulus}

Pelepasan renin dari kompleks jukstaglomerulus melibatkan second messengger yaitu cAMP dan kalsium. Semua faktor yang merangsang cAMP dalam sel-sel jukstaglomerulus, termasuk prostaglandin, kinin, dan agonis $\beta$-adrenergik, memiliki efek perangsangan terhadap pelepasan renin. Protein kinase merupakan sinyal transduksi siklik nukleotida yang penting, dan cAMP bekerja pada protein kinase A, sehingga akan meningkatkan suatu kaskade yang menghasilkan pelepasan renin dari granula penyimpanan dalam sel-sel jukstaglomerulus. Selain itu, sekresi renin juga dirangsang oleh penurunan kalsium ekstrasel in vitro, dan juga penurunan kalsium intrasel. $^{12}$

Pelepasan renin dari sel-sel jukstaglomerulus merupakan tahap pertama dan satu-satunya tahapan yang mengaktifkan sistem renin-angiotensin yang dikendalikan oleh beberapa mekanisme, yaitu: tekanan perfusi ginjal yang rendah (baroreseptor ginjal), aktivasi sistem saraf simpatis, penurunan pengiriman garam dari makula densa, dan penurunan kerja dari hormon lokal. Keempat mekanisme tersebut akan meningkatkan kadar renin dalam sirkulasi maupun dalam interstisium sehingga menyebabkan peningkatan generasi angiotensin I yang kemudian dikonversi menjadi angiotensin II. ${ }^{12-16}$

\section{Mekanisme makula densa}

Pengaturan pelepasan renin dari ginjal sangat kompleks. Salah satu mekanisme yang mengendalikan sekresi renin dari selsel jukstaglomerulus ialah mekanisme makula densa. Makula densa mengatur hubungan timbal balik antara konsentrasi natrium klorida dalam tubulus distal ginjal dan konsentrasi plasma renin. ${ }^{17}$ Tempat 
masuk dari $\mathrm{NaCl}$ ke dalam sel-sel makula densa terutama melalui NKCC2 yang terdapat pada permukaan apikal makula densa dan melalui NHE2. Perubahan pengiriman $\mathrm{NaCl}$ dalam tubulus ke makula densa menciptakan sinyal untuk memodifikasi pelepasan renin dari sel-sel jukstaglomerulus. Peningkatan glomerular filtration rate (GFR) akan meningkatkan pengiriman $\mathrm{NaCl}$ pada tubulus distal, dan perubahan ini dikenal oleh sel-sel makula densa. Sinyal tersebut kemudian menjadi umpan balik untuk sel-sel jukstaglomerulus dan arteriol aferen. ${ }^{12}$

Peningkatan pengiriman $\mathrm{Na}^{+}$ke segmen tebal asendens akan meningkatkan aktifitas NKCC2, sehingga terjadi peningkatan natrium dalam sel-sel makula densa. $^{12}$ Makula densa membangkitkan sinyal yang memicu sintesis dan pelepasan renin jika terjadi penurunan konsentrasi $\mathrm{NaCl}$ dalam tubulus ginjal. ${ }^{3}$ Perubahan konsentrasi $\mathrm{NaCl}$ dalam lumen tubulus akan memulai suatu proses elektrokimiawi dalam sel-sel makula densa, termasuk perubahan konsentrasi ion-ion intrasel, potensial membran dan volume sel. Sel-sel makula densa dapat berkomunikasi dengan sel mesangium, sel otot polos arteriol aferen, dan sel granular jukstaglomerulus melalui pelepasan ATP pada permukaan basolateral makula densa; dan juga melalui $\mathrm{PGE}_{2}$ dan produksi nitrik oksida. ${ }^{18-20}$ Sinyal yang dihasilkan oleh makula densa kemudian dikirim ke sel-sel jukstaglomerulus untuk melepaskan renin ke dalam sirkulasi maupun ke dalam interstisium. $12,13,21$

Penurunan konsentrasi $\mathrm{NaCl}$ in vivo yang dikirim ke makula densa merangsang sekresi renin melalui suatu mekanisme yang diperantarai COX-2. Ekspresi COX-2 meningkat ketika konsentrasi $\mathrm{NaCl}$ rendah atau ketika NKCC2 dihambat oleh diuretik. Penurunan paparan $\mathrm{NaCl}$ ke sel-sel makula densa menyebabkan sintesis $\mathrm{PGE}_{2}$. Sintesis $\mathrm{PGE}_{2}$ juga disebabkan oleh pening-katan aktivitas COX-2. Paparan rendah ga-ram yang lama juga dapat meningkatkan ekspresi COX-2 dalam jalur yang ter-gantung pada konsentrasi klorida. Hal ini juga disertai oleh pengaktifan p38 kinase dan ERK1/2 kinase. ${ }^{12}$

Penurunan aktifitas NKCC2 di dalam segmen tebal ascendens dan dalam makula densa mengakibatkan perubahan p38 dan aktifitas ERK1/2 MAPK. Hal ini menyebabkan terjadinya up-regulation dan aktivasi COX-2 yang meningkatkan sintesis dan pelepasan $\mathrm{PGE}_{2}$. $\mathrm{PGE}_{2}$ disintesis di dalam makula densa, kemudian dikirim ke reseptor $\mathrm{PGE}_{2}$ dalam sel-sel jukstaglomerulus yaitu EP4. Hal ini merupakan jalur makula densa yang terutama untuk merangsang adenilil siklase sel jukstaglomerulus dan produksi cAMP, yang akan menyebabkan peningkatan sekresi renin. ${ }^{12}$

Sintesis nitrik oksida neuronal (nNOS) dikendalikan oleh konsentrasi garam yang rendah. Stimulasi cAMP yang diperantarai oleh $\mathrm{PGE}_{2}$ diperkuat oleh cGMP yang dihasilkan oleh nNOS-NO. cGMP menghambat katabolisme cAMP oleh phosphodiesterase (PDE)-3, sehingga lebih menguatkan lagi formasi cAMP yang distimulasi oleh $\mathrm{PGE}_{2}$ dan memperkuat perangsangan cAMP terhadap pelepasan renin. ${ }^{12,17}$

Selain dapat mengenal perubahan konsentrasi $\mathrm{NaCl}$ tubulus, makula densa juga dapat mengenal keberadaan bahanbahan metabolit, seperti suksinat, melalui reseptor metabolit GPR91. ${ }^{13}$ Reseptor ini terekspresi sangat tinggi dalam ginjal dan mengikat suksinat sebagai ligannya. Reseptor ini ditemukan pada permukaan apikal sel-sel makula densa. Pengaktifan GPR91 berhubungan dengan ERK1/2 dan fosforilasi p38 dan pengaktifan COX-2 yang pada akhirnya akan memicu sintesis dan pelepasan $\mathrm{PGE}_{2}$. Sebagai vasodilator yang penting dan mediator parakrin, $\mathrm{PGE}_{2}$ memicu eksositosis renin dari sel-sel jukstaglomerulus. $^{13,21}$

\section{Aktivasi sistem saraf simpatis}

Mekanisme lain dalam pengontrolan sekresi renin yaitu perangsangan sistem saraf simpatis yang merangsang sekresi renin melalui reseptor $\beta$-adrenergik yang terdapat dalam sel-sel jukstaglomerulus. Sel-sel 
jukstaglomerulus berisi reseptor-reseptor $\beta 1$-adrenergik yang merupakan sebuah reseptor transmembran $G$ protein-coupled yang pada saat aktif akan memperbanyak sinyal-sinyal yang mengaktifkan adenilil siklase, merangsang fosfolipase dan mengubah saluran-saluran ion untuk menurunkan konsentrasi kalsium intrasel. ${ }^{12}$ Peningkatan sekresi renin sebagai respon terhadap rangsangan $\beta$-adrenoreseptor diperantarai oleh cAMP. Hormon, neurotransmiter, dan autakoid menaikkan produksi cAMP intrasel sehingga meningkatkan sekresi renin. ${ }^{12,22-24}$

Terdapat kontroversi mengenai peran dari cGMP. Beberapa pakar mengatakan bahwa cGMP juga merangsang sekresi renin namun ada juga yang melaporkan bahwa cGMP memiliki efek inhibisi terhadap sekresi renin. Terdapat interaksi penting antara cAMP dan cGMP terhadap sekresi renin melalui hidrolisis dari cAMP yang terjadi sebagai respon terhadap isoform PDE. PDE 3 berperan penting dalam sekresi renin yaitu ketika PDE 3 dihambat kerjanya oleh cGMP. cGMP dapat merangsang pelepasan renin dengan menurunkan kerusakan cAMP dengan cara melemahkan aktivitas PDE 3. Oleh karena itu, penghambatan PDE 3 juga akan menambah sekresi renin sebagai respon terhadap rangsangan $\beta$-adreno-reseptor. $12,22-24$

\section{Mekanisme baroreseptor ginjal}

Pelepasan renin telah terbukti bergantung pada penurunan tekanan perfusi tetapi tidak pada perubahan aliran darah ginjal. Sekresi renin dihambat oleh tekanan perfusi ginjal yang tinggi melalui mekanisme baroreseptor ginjal. Peningkatan perfusi ginjal dengan vasokonstriksi miogenik menyebabkan peningkatan tekanan, yang merupakan rangsangan utama untuk sintesis nitrik oksida endotel. ${ }^{12}$ Schweda et $\mathrm{al}^{25}$ telah mela-porkan bahwa penghambatan renin oleh karena peningkatan perfusi ginjal diperantarai oleh reseptor adenosin A1, yang menandakan bahwa formasi adenosin lokal merupakan faktor kunci dalam penghambatan baroreseptor ginjal. Penurunan perfusi ginjal menyebabkan vasodilatasi, mengubah formasi cAMP, dan meningkatkan sekresi renin. ${ }^{12}$

\section{Peran kompleks jukstaglomerulus terha- dap pengaturan resistensi pembuluh darah}

Kompleks jukstaglomerulus yang terdiri dari sel-sel jukstaglomerulus, makula densa, dan mesangium ekstraglomerulus merupakan komponen utama sistem reninangiotensin-aldosteron. Sistem renin-angiotensin-aldosteron ini teraktifasi melalui kerja renin yang dihasilkan dari kompleks jukstaglomerulus. Renin merupakan hormon kunci dalam sistem renin-angiotensinaldosteron. ${ }^{3,26}$

Kompleks juksta-glomerulus memiliki tiga komponen dan tiap-tiap komponen tersebut memiliki peran masing-masing dalam proses sintesis dan pelepasan renin ke dalam sirkulasi maupun ke dalam interstitium. Sel-sel dalam kompleks jukstaglomerulus berkomunikasi satu sama lain melalui suatu taut kedap. Dengan adanya taut kedap tersebut fungsi sintesis dan sekresi dalam kompleks jukstaglomerulus dapat berjalan dengan baik. ${ }^{14,27,28}$

Sel-sel jukstaglomerulus berperan dalam sintesis, penyimpanan, dan pelepasan renin. Sel-sel jukstaglomerulus merupakan satu-satunya sel dalam tubuh organisme yang menyintesis renin dalam bentuk preprorenin kemudian memrosesnya menjadi bentuk renin yang aktif dan menyimpan bentuk renin aktif tersebut dalam granula sekretorik dewasa. Sel-sel makula densa berperan dalam menciptakan dan mengirimkan sinyal untuk melepaskan renin dari dalam sel-sel granula jukstaglomerulus. Sinyal tersebut terbentuk ketika terjadi penurunan konsentrasi $\mathrm{NaCl}$ dalam tubulus distal ginjal. Sel mesangium ekstraglomerulus berperan sebagai sel penyokong yang juga mengirim informasi tentang $\mathrm{NaCl}$ di tubulus distal ke sel-sel jukstaglomerulus yang kemudian menyekresi dan melepaskan rennin. Sintesis renin oleh selsel juksta-glomerulus dipengaruhi oleh 
penurunan konsentrasi $\mathrm{NaCl}$ dalam tubulus distal, penurunan perfusi ginjal, stimulasi saraf simpatis melalui reseptor $\beta$-adrenergik, dan hormon lokal. ${ }^{14,27,28}$

Beberapa peneliti menjelaskan bahwa ketika terjadi penurunan konsentrasi $\mathrm{NaCl}$ dalam tubulus kontortus distal ginjal maka pengiriman $\mathrm{NaCl}$ ke sel-sel makula densa juga akan berkurang. Hal ini akan merangsang sel-sel makula densa untuk menciptakan sinyal yang akan memicu pelepasan renin dari sel-sel jukstaglomerulus. Penurunan konsentrasi $\mathrm{NaCl}$ juga akan menyebabkan terjadinya penurunan aktifitas NKCC2 yang menyebabkan perubahan pada aktifitas p38 dan ERK1/2 MAPK. Hal ini akan meningkatkan up regulation dan aktivasi COX-2 sehingga terjadi peningkatan sintesis dan pelepasan $\mathrm{PGE}_{2}$. $\mathrm{PGE}_{2}$ yang disintesis dalam makula densa akan dikirim ke sel-sel juksta-glomerulus dan ditangkap melalui reseptor $\mathrm{PGE}_{2}$ pada sel juksta-glomerulus (EP4). PGE $_{2}$ merangsang sintesis renin dengan cara mengakumulasikan cAMP dalam sel-sel jukstaglomerulus. Hal ini merupakan jalur utama bagi makula densa untuk merangsang produksi cAMP. Selain itu, pengurangan reabsorbsi $\mathrm{NaCl}$ akan menyebabkan penurunan konsentrasi kalsium dalam interstisum korteks ginjal. Peningkatan produksi cAMP dan penurunan konsentrasi kalsium intrasel akan menyebabkan peningkatan sekresi dan pelepasan renin. Selain penurunan pengiriman $\mathrm{NaCl}$, pelepasan renin juga dipengaruhi oleh penurunan tekanan arterial dan penurunan volume ekstrasel. ${ }^{16}$

Mekanisme pelepasan renin yang tidak melibatkan $\mathrm{NaCl}$ dan perfusi ginjal ialah mekanisme pelepasan renin yang melibatkan rangsangan sistem saraf simpatis. Sistem saraf simpatis merupakan pengatur penting dalam sekresi renin. Jalur klasik ini bekerja melalui aktivasi saraf $\beta$-adrenergik, yang akan meningkatkan produksi cAMP, kemudian akan merangsang sel-sel jukstaglomerulus untuk melepaskan renin. ${ }^{16,29}$

Renin yang dilepaskan ke dalam sirkulasi akan ditangkap oleh jaringan melalui reseptor renin pada jaringan tersebut. Renin diambil dari sirkulasi melalui pengikatan yang tidak spesifik pada sel-sel endotel pembuluh darah atau melalui suatu reseptor khusus untuk prorenin/renin. Reseptor M6P mengikat renin dan prorenin pada sel-sel endotel pembuluh darah. Beberapa peneliti menyatakan bahwa renin merupakan enzim protease aspartik, yang terutama dihasilkan oleh kompleks juksta-glomerulus, hanya akan terikat pada satu jenis substrat yaitu angiotensinogen. Walaupun angiotensinogen terutama diproduksi di dalam hati namun substrat ini juga termasuk dalam kaskade sistem renin angiotensin yang telah terdeteksi pada pembuluh-pembuluh darah melalui level mRNA. ${ }^{29,30}$

Renin akan mengubah angiotensinogen tersebut menjadi angiotensin I (dekapeptida) yang merupakan prekursor angiotensin II. Di dalam sirkulasi, angiotensin I secara cepat akan dikonversi oleh ACE (yang dominan terdapat pada permukaan sel-sel endotel dinding pembuluh darah) menjadi angiotensin II (oktapeptida). Angiotensin II merupakan produk utama dari sistem renin angiotensin yang memiliki efek vaso-konstriktor yang kuat. $^{30}$

Salah satu tempat kerja sistem renin angiotensin ialah pada dinding pembuluh darah. Pada sel-sel otot polos pembuluh darah terdapat reseptor $\mathrm{AT}_{1}$ yang memerantarai terjadinya vasokonstriksi. Salah satu fungsi sistem renin angiotensin ialah mengatur resistensi pembuluh darah ginjal dan pembuluh darah sistemik. Pengaturan resistensi pembuluh darah oleh sistem renin-angiotensin terjadi melalui kerja angiotensin II. Angiotensin II memiliki beberapa fungsi yang sangat penting, salah satunya yaitu dapat menimbulkan konstriksi pembuluh darah melalui reseptor $\mathrm{AT}_{1}$ sehingga terjadi peningkatan resistensi pembuluh darah. $^{30}$

Sistem renin angiotensin yang teraktifasi akan memroduksi angiotensin II. Sistem renin angiotensin hanya akan teraktifasi dengan adanya renin dalam sirkulasi. Sekali renin disekresi ke dalam sirkulasi maka akan terjadi serangkaian pemecahan angiotensinogen yang pada akhirnya 
akan menghasikan angiotensin II. Jadi, tanpa keberadaan renin dalam sirkulasi maka sistem renin angiotensin tidak akan teraktifasi. Dengan demikian, tidak akan dihasilkan angiotensin II yang akan menyebabkan konstriksi pembuluh darah; hal ini menunjukkan fungsi penting kompleks juksta-glomerulus terhadap pengaturan resistensi pembuluh darah. ${ }^{22,30}$

Kompleks jukstaglomerulus merupakan sumber utama renin dalam tubuh organism, dan akan memroduksi dan melepaskan renin ke dalam sirkulasi renin bila terjadi keadaan-keadaan seperti penurunan perfusi ginjal, dehidrasi, kehilangan cairan/ darah atau keadaan-keadaan yang menurunkan konsentrasi garam tubulus. Keadaankeadaan tersebut akan merangsang sel-sel makula densa, jukstaglomerulus, dan mesangium ekstraglomerulus untuk melaksanakan fungsinya masing-masing terhadap sintesis dan pelepasan renin dari kompleks jukstaglomerulus. Sel-sel makula densa bertindak sebagai penghasil sinyal dan mengirimkannya ke sel-sel jukstaglomerulus. Sel mesangium ekstraglomerulus membantu meneruskan sinyal yang dibentuk oleh sel-sel makula densa ke sel-sel juksta-glomerulus. Sinyal tersebut diterima oleh sel-sel jukstaglomerulus kemudian akan menyintesis dan melepaskan renin ke sirkulasi. $^{30,31}$

Selain itu, renin juga akan dilepaskan ke dalam sirkulasi bila terjadi perubahan konsentrasi angiotensin II dalam sirkulasi. Penurunan konsentrasi angiotensin II dalam tubulus dideteksi oleh sel-sel endotel dalam kompleks jukstaglomerulus, yang kemudian mengirim sinyal tersebut ke sel-sel jukstaglomerulus. Angiotensin II mengatur sekresi renin melalui suatu mekanisme homeostatis yang disebut "umpan balik pendek". ${ }^{31}$ Peningkatan konsentrasi angiotensin II dalam sirkulasi akan menghambat sintesis dan sekresi renin dari kompleks jukstaglomerulus, sedangkan penurunan angiotensin II memiliki efek berlawanan yaitu merangsang sintesis dan sekresi renin dari kompleks jukstaglomerulus. Dengan demikian keseimbangan resistensi pembuluh darah akan terpelihara baik. ${ }^{30,31}$

\section{Penghambatan sistem renin angiotensin aldosteron}

Sistem renin angiotensin aldosteron (SRAA) memiliki peran yang sangat penting dalam mengatur volume cairan tubuh dan pemeliharaan tekanan darah normal. Aktifitas SRAA yang berlebihan akan mengakibatkan terjadinya hipertensi dan kerusakan organ target. Dalam keadaan normal kerja SRAA diatur melalui mekanisme inhibisi kompensasi timbal balik oleh reseptor $\mathrm{AT}_{1}$ dalam pelepasan renin (Gambar 1). ${ }^{31}$

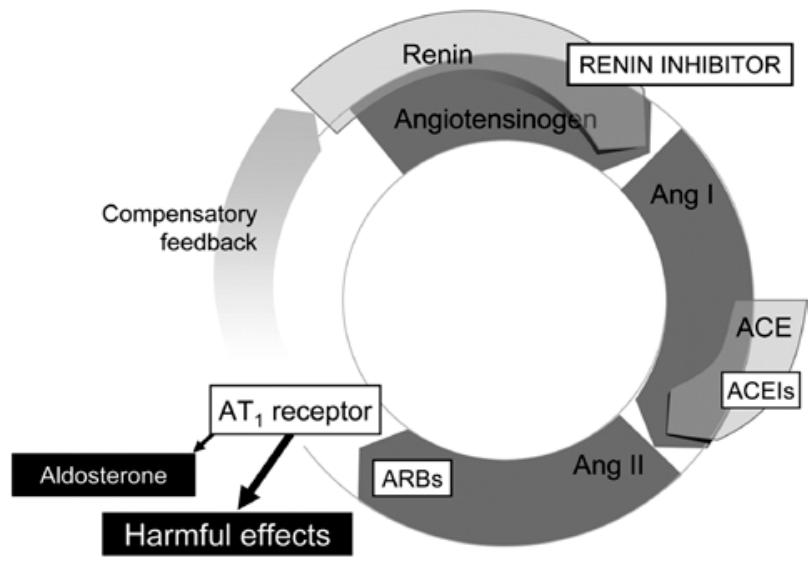

Gambar 1. Penghambatan sistem renin angiotensin aldosteron. Sumber: Müller DN, 2006. ${ }^{31}$

Penghambatan SRAA oleh angiotensin-converting enzyme inhibitors (ACEi) dan angiotensin receptor blockers (ARB) masih kurang efektif, oleh karena ACEi dan ARB hanya memutuskan mekanisme timbal balik sehingga terjadi peningkatan aktifitas rennin, yang pada akhirnya dapat meningkatkan konsentrasi Ang II melalui jalur konversi yang tidak tergantung jalur ACE, seperti dipeptidase, yang ditemukan pada beberapa jaringan, termasuk di ginjal. Penghambat renin bekerja secara langsung dan efektif untuk menghambat kerja SRAA dengan efek samping rendah. ${ }^{31}$ Walaupun ACEi dan ARB memiliki efek samping, sampai saat ini ACEi dan ARB masih digunakan secara luas sebagai terapi pilihan pada pasien hipertensi. 


\section{Penghambat langsung renin}

Konsep penghambatan SRAA melalui renin telah dimulai sejak 50 tahun silam. Demikian pula penemuan penghambat renin yang kuat bukan merupakan hal yang baru. Komposisi penghambat renin pada awalnya berupa penghambat peptida, seperti isovaleril-His-Pro-Phe-His-Sta-LeuPhe-NH2 (SCRIP), yang mengandung asam amino statin. Pepstatin merupakan penghambat renin sintetik yang pertama dan beberapa generasinya memiliki efektifitas yang sama dengan ACEi dalam menurunkan progesifitas penyakit gagal jantung akut, tetapi obat ini harus diberikan secara parenteral. ${ }^{22,31}$ Pada tahap lanjut, dikembangkan obat-obat oral seperti enalkiren, remikiren dan zankiren, tetapi penggunaan klinisnya masih sangat terbatas karena memiliki bioaviabilitas yang kurang $(<2 \%)$, masa paruh pendek, dan memiliki aktifitas antihipertensi lemah. ${ }^{22,31-33}$

Aliskiren merupakan penghambat renin pertama yang efektif digunakan secara oral, non-peptida dengan berat molekul rendah, serta efektif digunakan sebagai obat anti-hipertensi. ${ }^{32}$ Wood et al menggunakan teknik kombinasi antara analisis struktrur kristal kompleks penghambat renin dan metode komputasional untuk membentuk penghambat renin nonpeptida dengan berat molekul rendah. ${ }^{31-33}$ Aliskiren memiliki sifat kimia yang sangat hidrofilik, bioaviabilitas yang lebih baik, daya penghambat renin yang cukup kuat (IC50=0,6 nM) dengan afinitas yang tinggi terhadap renin, ${ }^{31,34}$ dan bekerja melalui celah antara kedua lobi yang menyusun renin, tempat dimana terjadi proteolitik angiotensinogen. ${ }^{22}$

Aliskiren dapat digunakan sebagai terapi alternatif pada pasien hipertensi. Aliskiren menghambat pemecahan angiotensinogen menjadi angiotensin I sehingga tidak akan dihasilkan angiotensin II melalui SRAA; tidak mempengaruhi metabolisme bradikinin, dan tidak meningkatkan konsentrasi angiotensin II dalam sirkulasi. ${ }^{32}$

Selain penghambatan SRAA melalui kerja penghambat renin langsung, juga dapat dikembangkan penghambat pada tempat sintesis renin yaitu kompleks jukstaglomerulus. Di dalam kompleks jukstaglomerulus terdapat sinyal-sinyal yang merangsang sintesis renin. Perlu dikembangkan metode atau bahan tertentu yang dapat menghambat sinyal-sinyal tersebut sehingga produksi renin dapat dihambat.

Cara lain yang mungkin dapat dikembangkan ialah penghambatan fungsi taut kedap yang merupakan saluran komunikasi intersel dalam kompleks jukstaglomerulus.

\section{SIMPULAN}

Kompleks jukstaglomerulus berperan penting dalam pengaturan resistensi pembuluh darah. Kompleks jukstaglomerulus dirangsang oleh sejumlah keadaan seperti tekanan darah rendah, kehilangan cairan tubuh, dan kurangnya intake natrium yang menyebabkan sintesis dan pelepasan renin ke sirkulasi.

Renin akan memecah angiotensinogen menjadi angiotesin I, kemudian angiotensin I secara cepat dikonversi oleh angiotensin converting enzyme (ACE) menjadi angiotensin II. Angiotensin II menyebabkan vasokontriksi seluruh pembuluh darah sehingga meningkatkan resistensi pembuluh darah, yang berakibat peningkatan tekanan darah.

ACEi dan ARB kurang sempurna dalam menghambat kerja SRAA oleh karena keduanya memutuskan rantai mekanisme timbal balik sehingga terjadi peningkatan renin. Penghambat renin lebih efektif menghambat aktifitas SRAA dan dapat digunakan sebagai obat antihipertensi dengan efek samping rendah.

Penghambatan SRAA yang juga dapat dikembangkan ialah penghambat sintesis renin dalam kompleks jukstaglomerulus, yaitu dengan cara menghambat sinyalsinyal dalam kompleks jukstaglomerulus yang merangsang sintesis renin dan menghambat fungsi taut kedap yang terdapat dalam kompleks juksta-glomerulus. 


\section{DAFTAR PUSTAKA}

1. Tessy A. Hipertensi pada penyakit ginjal. In: Buku Ajar Ilmu Penyakit Dalam Jilid I (Edisi IV). Jakarta: Pusat Penerbitan Departemen Ilmu Penyakit Dalam Fakultas Kedokteran Universitas Indonesia. 2006: 604.

2. Nafriadi. Antihipertensi. In: Buku Farmakologi dan Terapi (Edisi 5). Jakarta. Balai Penerbit FKUI. 2008:341.

3. Hanner F, Chambrey R, Bourgeois S, Meer E, Musci I, Rosivall L, et al. Increased renal renin content in mice lacking the $\mathrm{Na}^{+} / \mathrm{H}^{+}$exchanger NHE2. Am J Physol Renal Physol. 2008;294: F937-44.

4. Schnermann J. The juxtaglomerular apparatus: from anatomical peculiarity to physiological relevance. J Am Soc Nephrol. 2003;14:1681-94.

5. Yao J, Oite T, Kitamura M. Gap junctional intercellular communication in the juxtaglomerular apparatus. Am J Physiol Renal Physiol. 2009;296:F93946.

6. Kobori H, Nangaku M, Navar LG, Nishiyama A. The intrarenal reninangiotensin system: from physiology to the pathobiology of hypertension and kidney disease. Pharmacological Reviews, 2007.

7. Savaskan E. The role of the brain reninangiotensin system in neurodegenerative disorders. Current Alzeimer Research. 2005;2:29-35.

8. Klabunde RE. Cardiovascular physiology concepts: renin-angiotensin-aldosterone system. 2007 [cited 2010 Nov 18]. Available from: www.cvphysiology. com/Blood\%20 Pressure/BP015.htm.

9. Harrison LM. The renal renin-angiotensin system. Advan Physiol Edu. 2009;33:270-4.

10. Victor XVA. Angiotensin II- mediated regulation of the human angiotensin II type I receptor gene. Departement of Chemistry and Biochemistry Bringham Young University, Desember 2005.

11. Nguyen G, Delarue F, Burcklé C, Bouzhir L, Giller T, Sraer JD. Pivotal role of the renin/prorenin receptor in angiotensin II production and cellular responses to renin. J Clin Invest. 2002; 109(11):1417-27.
12. Beierwaltes WH. The role of calcium in the regulation of renin secretion. Am J Physiol Renal Physiol. 2010;298:F1-11.

13. Peterdi JP, Harris RC. Macula densa sensing and signaling mechanisms of renin release. J Am Soc Nephrol. 2010; 21:1093-96.

14. Peterdi JP, Fintha A, Fuson AL, Tousson A, Chow RH. Real-time imaging of renin release in vitro. Am J Physiol Renal Physiol. 2004;287:F329-35.

15. Murray RK, Granner DK, Mayes PA, Rodwell VW. Biokimia Harper (Edisi 25). Jakarta: EGC, 2003.

16. Aoyagi T, Izumi $Y$, Hiroyama $M$, Matsuzaki T, Yasuoka Y, Sanbe A, et al. Vasopressin regulates the reninangiotensin-aldosterone system V1a receptors in macula densa cells. Am J Physiol Renal Physiol. 2008;295: F100-7.

17. Persson PB. Renin: origin, secretion and synthesis. J Physiol. 2003 Nov 1;552(Pt 3):667-71.

18. Kovács G, Komlósi P, Fuson A, Peterdi JP, Rosivall L, Bell PB. Neuronal nitric oxide synthase: its role and regulation in macula densa cells. J Am Soc Nephrol. 2003;14:2475-83.

19. Komlosi P, Peterdi JP, Fuson AL, Fintha A, Rosivall L, Bell PB. Macula densa basolateral ATP release is regulated by luminal $[\mathrm{NaCl}]$ and dietary salt intake. Am J Physiol Renal Physiol. 2004;286: F1054-8.

20. Komlosi $P$, Frische S, Fuson AL, Fintha A, Zsembery A, Peterdi JP, Bell PD. Characterization of basolateral chloride/bicarbonate exchange in macula densa cells. Am J Physiol Renal Physiol. 2005;288:F380-6.

21. Vargas SL, Toma I, Kang JJ, Meer EJ, Peterdi JP. Activation of the succinate receptor GPR91 in macula densa cells causes renin release. J Am Soc Nephrol. 2009;20:1002-11.

22. Karundeng R. Peran renin pada sistem renin angiotensin aldosteron. Biomedik. 2008;4(3):106-12.

23. Persson PB, Skalweit A, Mrowka R, Thiele BJ. Control of renin synthesis. Am J Physiol Regul Integr Comp Physiol. 2003;285:R491-7.

24. Friis UG, Jensen BL, Sethi S, Andreasen D, Hansen PB, Skøtt O. Control of 
renin secretion from rat juxtaglomerular cells by cAMP-specific phosphodiesterases. Circulation Research. 2002;90:996.

25. Schweda F, Klar J, Narumiya S, Nüsing RM, Kurtz A. Stimulation of renin release by prostaglandin E2 is mediated by EP2 and EP4 receptors in mouse kidneys. Am J Physiol Renal Physiol, 2004;287:F427-33.

26. Wetze RK,

\section{Sweadner}

KJ.

Phospholemman expression in extraglomerular mesangium and afferent arteriole of the juxtaglomerular apparatus. Am J Physiol Renal Physiol. 2003;285:F121-29.

27. Wikipedia. Juxtaglomerular apparatus. [cited 2010 Nov 6]. Available from: http://en.m.wikipedia.org/wiki/Juxtaglo merular_apparatus.

28. Klabunde RE. Cardiovascular physiology concept: renin-angiotensin-aldosterone system [homepage on the Internet]. 2007. [updated 2007 Jun 04; cited 2010 Nov 18]. Available from: www. cvphysiology.com/Blood\%20Pressure/ BP015htm.

29. Schweda F, Friis U, Wagner C, Skott O,
Kurtz A. Renin release. Physiology. 2007;22(5);310-9.

30. Paul M, Mehr AP, Kreutz R. Physiology of local renin-angiotensin systems. Physiol Rev. 2006;86:747-803.

31. Müller DN, Luft FC. Direct renin inhibition with aliskiren in hypertension and target organ damage. Clin J Am Soc Nephrol. 2006;1(2):221-8.

32. Gradman AH, Schmieder RE, Lins RL, Nussberger $\mathrm{J}$, Chiang $\mathrm{Y}$, Bedigian MP. Aliskiren, a novel orally effective renin inhibitor, provides dosedependent antihypertensive efficacy and placebo-like tolerability in hypertensive patients. Circulation. 2005;111:1012-8.

33. Pilz B, Shagdarsuren E, Wellner $M$, Fiebeler A, Dechend R, Gratze P, et al. Aliskiren, a human renin inhibitor, ameliorates cardiac and renal damage in double-transgenic rats. Hypertension. 2005;46:569-76.

34. Bell PD, Lapointe JY, Sabirov R, Hayashi S, Peterdi JP, Manabe K, et al. Macula densa cell signaling involves ATP release through a maxi anion channel. PNAS. 2003;100(7):4322-7. 